\title{
Health, Local Culture and Environment Cultural Strategies of Local Communities in Dealing With Scarcity of Health Access Due to Environmental Conditions
}

\author{
Martinus Legowo ${ }^{1}$, FX Sri Sadewo ${ }^{2}$, Refti Handini Listyani ${ }^{3}$, and Farid Pribadi ${ }^{4}$ \\ \{marleg@unesa.ac.id ${ }^{1}$, fsadewo@unesa.ac.id ${ }^{2}$, reftihandini@unesa.ac.id ${ }^{3}$, and \\ faridpribadi@unesa.ac.id $\left.{ }^{4}\right\}$ \\ ${ }^{1,2,3,4}$ Universitas Negeri Surabaya, Indonesia
}

\begin{abstract}
Infrastructure development in Indonesia has taken place in the last five years. However, in a number of areas the community has not been able to connect properly, especially in eastern Indonesia. They cannot access health facilities that are more likely in urban areas. This limited access is caused by various things. First, limited medical personnel. Second, facilities that are inadequate due to environmental problems. Difficult distances and terrain are the main obstacles. Through ethnographic research, in a number of local communities in South Sorong Regent and Teluk Wondama Regent, researchers looked at various strategies and local wisdom turned out to have been able to overcome health problems, so it did not become a disaster.
\end{abstract}

Keywords: Local Community, Local Wisdom, Health, Environment

\section{Introduction}

Health status is one indicator of a nation's social welfare. Health status shows the quality of life of the people. This can be achieved if the government really implements health development programs. Through these programs, the government hopes that health status will increase. This health status is an indicator of human development. This is indicated by life expectancy in the human development index [1]-[3].

To strengthen the human development index, the Indonesian government through the Ministry of Health developed a special index for health development. The index is known as the public health development index (IPKM). The measure will refer to the indicators behind life expectancy. Life expectancy is the outcome of the achievement of other health indicators. These indicators cannot be separated from an understanding of health status according to H.L. Blum. In theory, health status is influenced by the environment, physical health and lifestyle services. The index has been developed since 2010. In its development, there are 30 indicators. These indicators can be grouped into 6 (six), namely: infant health, reproductive health, health services, health behavior, non-communicable diseases, infectious diseases and environmental health. [4]

With this index, the government easily describes the achievement of improving the quality of public health. It is not inseparable that the health development effort has been carried out since the beginning of independence. Because the national problems were far more advanced, the health problems did not increase significantly during the Sukarno administration. However, when faced with the problem of malaria, the Sukarno government immediately 
responded with a spraying program. Meanwhile, the Suharto government was far more fortunate. They can also focus on economic development. This was stated in the development trilogy. Because humans are one of the basic capital, the government also improves its quality with health development. For this reason, the government established health centers in each sub-district throughout Indonesia. What is done is already right because a number of studies have shown that there is a correlation between income and quality of health. One indicator of the quality of health is life expectancy. This correlation is shown in figure 1 [5].

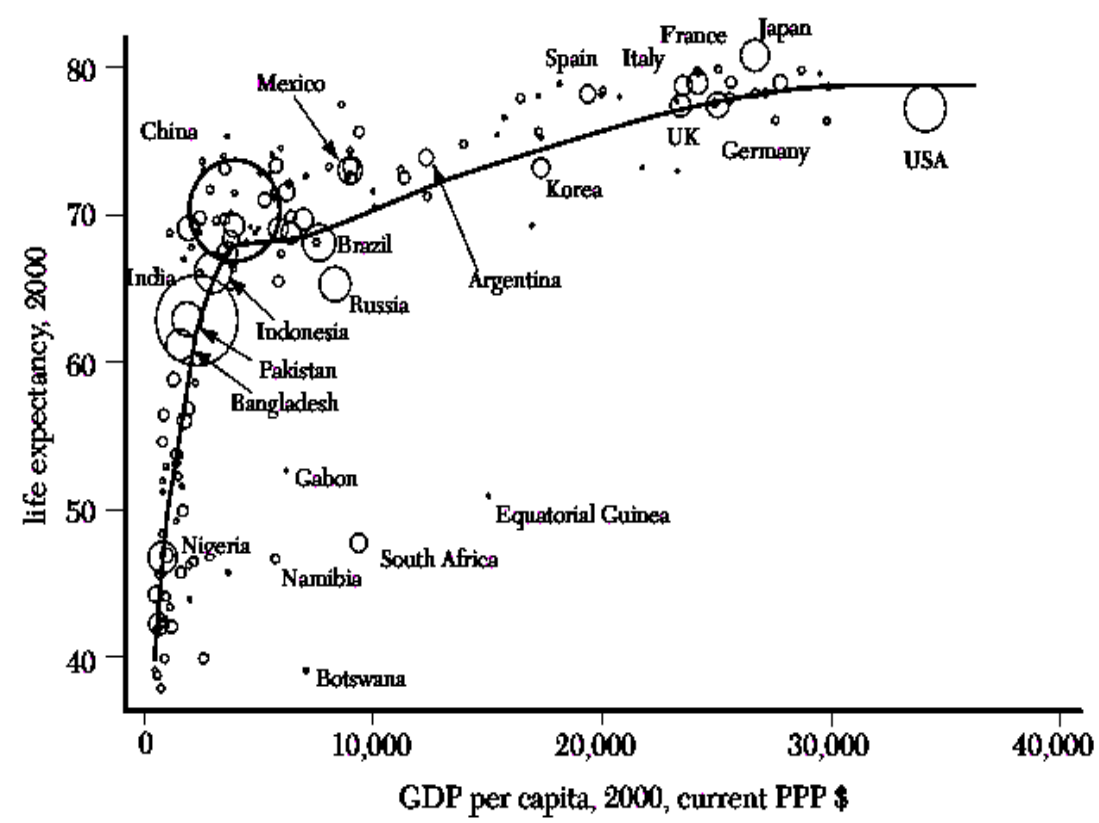

Fig. 1 Life Expectancy Rate and GDP per capita[5]

Other data shows that improving access to health services during the Suharto government turned out to be uneven. [6] The problem is not only the availability of health facilities, but also the ability of the community, especially poor families to access them. The government has provided subsidies, but in reality at that time more pro-middle class families than poor families. Nonetheless, the government actually has sought with a certificate of incompetence (as poor family).

In economic (monetary) crisis situations, health problems are an important factor in the family's economic recovery. In response to this, health subsidy programs are included in social safety net schemes. Poor families no longer submit letters of resentment, but have received health insurance cards. These health insurance for poor is subsidized by the government. Even with this scheme, not all people can use the facility. There are a number of markers of this statement, one of which is the infant and maternal mortality rate that has not decreased significantly. Even so, not only is the issue of access to health services a contributing factor.[7]

The issue of access to health is stronger in provinces in eastern Indonesia, such as NTT, Maluku, North Maluku, West Papua and Papua. Scarcity of health access is caused by several things. First, the limitations of health facilities. One of the causes is the characteristics of the 
districts. There are very wide districts, there are also island districts. These two characteristics lead to obstacles in accessing health services. Second, the number of health workers is limited.[8] With the characteristics of the region, the number of health workers needed is certainly greater. Although the population served is less, area coverage by a health personnel is much broader, as in the case of Teluk Wondama Regency, West Papua.[9]

Health problems, especially in Papua and West Papua for example, vary widely. In terms of infectious diseases, as in the eastern part of Indonesia, the prevalence of malaria is still very high in almost all regencies. This is related to environmental health issues. Environmental health problems also cause the prevalence of diarrheal diseases. The next problem is the problem of malnutrition. This situation did not actually occur in the post-Suharto era, but it had been going on since before it was integrated with Indonesia (or returned by the Dutch) in the 1960s. The problem is how they become sustainable in the midst of limited health facilities and facilities.

\section{Research Method}

This article is the result of a comparison of two ethnographic studies from two communities with two different districts in West Papua. The Mairasi community is in Wombu Village, Naikere District, Wondama Bay Regency. The Mairasi community is actually a group of three ethnic groups, namely: the Mairasi tribe, the Toroar tribe and the Mere tribe. Naikere District is approximately $100 \mathrm{~km}$ from the capital city by road or about $50 \mathrm{~km}$ by sea.

Ethnographic research was carried out by a research team at the Center for Humanities and Health Management, Health Research and Development Institute of the Indonesian Ministry of Health. One of the authors, FX Sri Sadewo, was a member of the research team in Wombu Village in 2014, while Martinus Legowo was a member of the research team of Intervention Research in Kampung Konda and Wamargege, Konda District, South Sorong in 2018. Intervention research is a continuation of ethnographic research or more precisely participatory research. The technique of data collection is done by observing for 2 (two) months by living with the community.

During their stay with the community, the team conducted interviews with local leaders, formal leaders, health workers and families. Some of the things that became the topic of the interview, among others: clean and healthy behavior to health seeking, and social values that support the quality of health. These things are also supported by observations.

\section{Result and Discussion}

\subsection{New Regencies with Health Problem}

South Sorong Regency and Wondama Bay Regency are two new regencies. Teluk Wondama Regency was expanded from Manokwari Regency (in 2003). The district was originally one of the districts of the old district. However, in contrast to the sub-districts in Java, this sub-district has an extraordinary area. Most of the area is forest and a small portion of settlements and cultivation. Most settlements are in the coastal area (Wasior and its surroundings), especially migrants. Others are sporadically in hilly, inland areas. The choice of living in a hilly, inland region turned out to be an extraordinary local wisdom. The coastal area turned out to be an area of sendimen landslides from the hills in the interior. This is 
inseparable from the structure of landslides that are prone to landslides. Landslides and flash floods occur several times. The biggest incident was in 2010 and repeated in 2013. Therefore, they intended to move the center of the district capital in Rasiei even though the threat also remained.

Meanwhile, South Sorong Regency is the last division of Sorong Regency in the same year as Wondama Bay Regency. Sorong Regency with extraordinary natural resources has become an attraction for migrants. As a result, this district is growing rapidly. This district is much larger than Manokwari Regency which is the capital of West Papua Province. Besides South Sorong Regency, the expansion area of Sorong Regency is Sorong City. As a new district, this region has adequate health facilities and health providers. The same is true in Teluk Wondama district.

Table 1. Indicators of Human Development at South Sorong and Wondama Bay [10]-[12]

\begin{tabular}{lrrr}
\hline No. Characteristic & $\begin{array}{r}\text { South } \\
\text { Sorong }\end{array}$ & $\begin{array}{r}\text { Wondama } \\
\text { Bay }\end{array}$ & $\begin{array}{r}\text { Prov. Papua } \\
\text { Barat }\end{array}$ \\
\hline Region & $7.789,92$ & $14.953,80$ & $102.955,15$ \\
Population & 45.019 & 31.072 & 915.361 \\
District & 15 & 13 & 218 \\
Hospital & 1 & 1 & 14 \\
Primary Health Care & 6 & 15 & 154 \\
(Puskesmas) & 12 & 33 & 370 \\
Doctor & 3.752 & 942 & 2.474 \\
a. Ratio per population & 649 & 453 & 278 \\
b. Ratio per region & 182 & 294 & 2.526 \\
Nurse & 247 & 106 & 362 \\
a. Ratio per population & 43 & 51 & 41 \\
b. Ratio per region & 35 & 58 & 895 \\
Midwifery & 1.286 & 536 & 1.023 \\
a. Ratio per population & 223 & 258 & 115 \\
b. Ratio per region & 59,26 & 65,63 & 65,32 \\
Life expectancy & 10,81 & 12,28 & 12,47 \\
Mean Years of Schooling & 7,7 juta & 5,904 juta & 7,493 juta \\
Index & 58,10 & 60,19 & 62,69 \\
Income Index & 0.5255 & 0.6338 & \\
Human Development Index & $(429)$ & $(339)$ & \\
Public Health Development & & & \\
Index & & & \\
\hline
\end{tabular}

From the social welfare records of each district, there are several problems faced. First, related to clean and healthy living behavior (PHBS), especially the availability of clean drinking water. This was experienced by South Sorong Regency. Only $45.70 \%$ of households have clean water[10]. A far better reality than the people of Wondoma Bay Regency, which is only $31.25 \%$, uses clean drinking water.[11] The location of settlements in the interior and coastal areas far from urban areas has resulted in difficulties in providing clean water. In Konda District, South Sorong Regency, construction of new waterways has just begun. The problem is geographical factors and transportation routes that do not support. The Konda community, especially in the villages of Konda and Wamargege, rely more on rainwater. This situation is better experienced by the community of Naikere District with clean water 
available. This clean water relies on the river. Because erosion often occurs, the water quality will change if rain arrives.

Health profile data, the morbidity rate of South Sorong Regency is much lower than Wondama Bay District. Morbidity figures Wondama Bay Regency ranks 4th in West Papua Province, after Manokwari Regency, South Manokwari and Sorong Regency. The three districts that experience the highest morbidity rates do face various health problems because they are related to population growth in the process of urbanization in a region. Environmental health issues and availability of facilities are more advanced. This is actually also felt by Teluk Wondama Regency related to malaria problems.[13] The prevalence of this disease ranks second after Manokwari Regency. The prevalence of this disease is inseparable from environmental conditions that accelerate the increase of mosquito vectors. On the other hand, malaria is a national concern because West Papua Province is ranked second highest after Papua Province. [14]

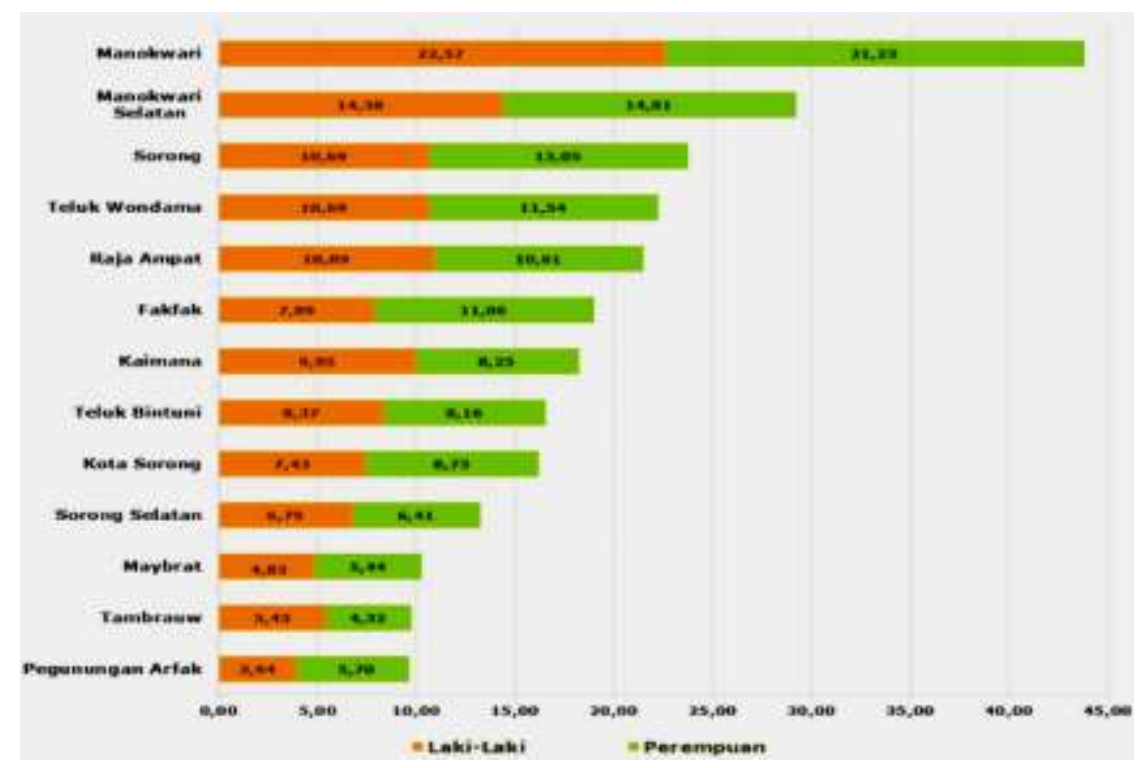

Fig. 2. Mortilty Rate of West Papua [13]

\subsection{Local Wisdom for Problem Solving}

Local Elite Role: Return to Learning from Ancestors. In Papuans, including West Papua, prominent local elites are tribal chiefs. In Konda District, South Sorong Regency, there are three tribes, namely: Yaben, Nakna, and Afsyah. Each tribe is headed by a chieftain. They are responsible for resolving customary issues. Different in South Sorong Regency, the Naikere District community has a large tribal chief, Mairasi. He led three tribes. He oversees the Mere, Toroar and Mairasi tribes. Its power extends beyond the district boundaries to the Regency. Kaimana. In each village, traditionally the community must submit to the village tribal chief.

These village chiefs were chosen by the community based on the principle of primus inter pares. Their ancestors were "great" people in everything, starting from war, wisely in overcoming customary problems to treating sick people. "Supernatural" abilities are revealed to 
their offspring. This offspring replaces his father if he is gone. The existence of the Mairasi high chief who can supervise the three tribes is inseparable from its history. During the Dutch colonial rule, there was a war between the three tribes. One reason is the migration of one tribe to the interior. The war was finally resolved at the crossing of the Wosimo-Wombu river with an agreement. Machetes was broken as a marker of the end of the war and was appointed by the high chief in charge of the three tribes.

Administratively, each village is led by the village head. The head of the village takes care of population and development issues, ranging from making population identities, rural development programs, to special autonomy funds. The village head was originally formed by the Dutch colonial government. They occupy the same position as village heads in other parts of Indonesia. The village head was chosen by the community and appointed by the Regent. They are assisted by the village secretary who is on average a state civil apparatus. Besides the village secretary, there are a number of heads of affairs, such as the head of government affairs and the head of social welfare affairs. The Head of the Village is under the coordination of the head of the District. Unlike the Naikere district, one of the village heads in the Konda District turned out to also be a tribal chief.

Regarding the issue of health development, facilities and health personnel in the Konda district are far more complete than the Naikere District. In Konda District, there is a health center with a midwife and nurse (mantri). Both health workers prefer to open services at home. One reason, when opening a health center, the whole community quickly arrived, although not necessarily sick and asking for medicine, so that the stock could be used up in a day (drug reservoir). The same pattern is carried out by the Naikere District community if there are visits by health workers from the district office. What is different from Konda District is that there are no permanent health workers. The Primary Health Center (Puskesmas) was previously in Wombu Village. For some reason, the puskesmas and the district office were moved to a new place. The new place is very separate from the six villages. Due to limited water sources in the new location, up to now both the district office and the health center are not occupied.

Under these conditions, the chief of the tribe cooperated with the village head who was very active in dealing with health problems. In connection with this problem, tribal leaders actively build relationships with health workers and health services. They, especially the great chief of the Mairasi tribe, were happy to deliver visiting staff from village to village. To reach another village, they have to walk for days. When in the village, they visit from house to house to check the health condition of the community. Because they are far from the main road, they once coordinated all of their citizens to collect their citizens on stretchers.

When health workers are absent or inadequate medicine, they begin to re-use the teachings of their ancestors about herbal medicines. Knowledge and treatment skills were obtained from his father a few days before he died. They are usually invited by their father to go into the forest. At that time, they were asked to fast. For about three days or more his father spoke various things, including traditional medicine. There are times when the knowledge and skills are shared with the closest parties to their children. For example, the Wombu tribal chief was only given negotiations with outside parties, predicted and treated from occult matters to medical illness, except women's reproductive health. The ability to obey women was given to his wife. The reason given by his father was that in the arena of his ability, he would travel more outside the village to negotiate with the government. Therefore, to take care of women, his wife was given an magical skill needed to overcome health problems.

Solidarity for Sharing Social Obligation and Proteins. In the Konda District, the use of herbal medicines is also known and studied by health workers. Knowledge and skills in 
processing herbal medicines were obtained from his parents and also from his tribal chief. They just take leaves from the surrounding environment. Unlike in the Naikere District, the availability of medicinal plants in the Konda District is far limited. Its beachfront location with sandy soils limits plant variants. In the Naikere District, their location is far from the beach. The surrounding environment is dense forest. The people, especially the chiefs, are very familiar with plants that can be used for medicine. There are plants that are used for medicine, there are also for magical things, and there are also for vegetables.

Knowing modern medicine and medical personnel, this knowledge also gradually diminished. They are not aware that having biodiversity is useful for health. Once, one of the village heads in the Naikere District had to experience a cold sore due to a malaria attack for several days. After there were medical personnel, he was just taken for treatment. After starting to heal, he and the new tribal chief remembered that there were leaves of certain plants that could be used to treat.

This is a consequence of the limited supply of medicines because of the location far from the district capital and transportation barriers. If the road is not damaged, then to go to the district capital simply by road. In fact, they have to go by sea / river. This not only happened in Konda District, South Sorong Regency. The same thing was experienced by the Naikere District community, Wondama Bay Regency. The Naikere District community must walk first to the pier (logpon). The distance depends on where the village comes from. The closest village, namely Wombu Village, is $25 \mathrm{~km}$, the most far more than $60 \mathrm{~km}$ and is not always located right on the road crossing Papua (West). The road is not flat, but through several hills.

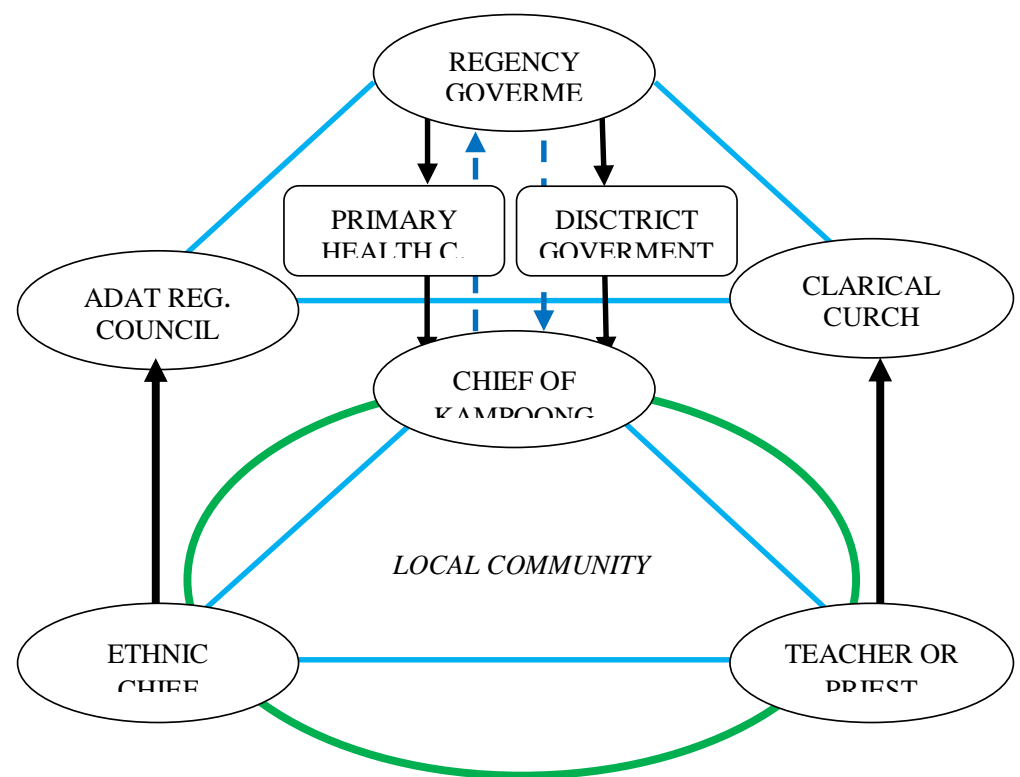

Fig. 1 Relations between communities, traditional and religious institutions

The surrounding environment is a source of food. In addition to farming around the house, such as bananas, cassava trees, chili and eggplant, they collect food, hunt animals in the forest and catch fish and shrimp. The Naikere District community catches fish in the river, the Konda community at sea. In addition to fish and shrimp, the Konda community collects shellfish. When hunting in the forest, such as wild boar and deer, they are helped by dogs. The 
dogs run, sniff and chase animals. The owner only needs to spear or archery if it is to be consumed immediately. Or, they set a trap to maintain. In accordance with adat, and following the preaching of the priests, they will share the results. The results were shared with the closest neighbors around his house. The tradition of sharing hunting proceeds is very thick to the Mairasi community in the interior, especially in the Kaimana regency. Even though there are only a few, each family will receive hunted meat.

Unlike the Konda District, the Mairasi community does not always hunt wild boar and deer, or / and collect fish and shrimp every day. They do it especially if there are traditional events at home. On other days they rely more on crop yields in the surrounding environment, such as fruits and vegetables. Because the company's CSR program is logging, they learn to raise chickens. Chicken is not eaten, only the eggs are taken. They never eat meat that is not hunted. Only if they want meat, they just go to a river that is not far from his house to catch fish and shrimp. When hunting wild boar and deer, they must go far. Wild boar and deer have run deep in the forest. They avoided large vehicles carrying timber. On the other hand, the Naikere people were unable to compete with employees of timber and mining companies who used rifles. Once hunting, for several days, the community of Naikere only got one tail and often returned empty-handed. They, employees of timber and mining companies can get more than three animals overnight. Unfortunately, for hunting, they asked for help from local residents, but did not want to share it when they got it.

The tradition of sharing is still ongoing until now not only delivered by the chiefs, but also taught continuously by the clergy. Priests or precisely religious teachers have a special position in the Konda and Naikere communities. Through their sermons in the church every week, they remind the meaning of togetherness on the one hand. On the other hand, they also reminded how important family health is and a number of rural development programs. This is inseparable from good communication between religious teachers and village heads and tribal leaders. When conducting customary activities, the priest or religious teacher is always asked to say a prayer before eating. They are also involved in various things, from building houses, opening gardens to funerals.

\section{Conclusion}

Within the West Papuan community, these three local elites are symbolized by the term one stove of three stones. Although the formation since the days of the Dutch colonial government, the position of the village head was strong because he became a key figure in carrying out development programs, both initiatives originating from the local community and from the government. The head of the tribe has contributed not only to addressing indigenous issues, from rites of life circles to community rites, but also helped and pressured the district government in meeting community needs. They are very responsive to the basic needs and problems faced by the community. They also acted as mediators in dealing with conflicts between the community and the village head, between the community and the company, between the community and the district government. Because of the position of this powerful chief, district officials often had to come to see him if there were problems he faced.

Especially in Naikere District, not only magically, chieftains also possess extraordinary political thinking skills. They are negotiating experts, they are also political strategists. They drafted the nominations of councilors so that they could be elected in legislative elections. Through closeness with voters, they explain their strategy. According to him, in this way, they can convey their aspirations to the district government. Elected members of the council are 
briefed on what must be fought for. Members also must convey what is done if they want to be elected in the next period. Meanwhile, the same thing with a different strategy was carried out by one of the chiefs in Konda District. To be able to access administratively, he volunteered as village head and was elected by the community. At every meeting with the regents and regents, the tribal chief fought hard for all basic needs, including in the health sector.

Together with the pastor and/or religious teacher, the head of the tribe continues to develop local traditions, one of which is sharing hunting results and studying herbal medicines of ancestral heritage. These herbal medicines are used as the first treatment and if they experience scarcity of drugs from medical personnel. It should be noted that this hierarchical church structure also makes it easier for clergy and/or religious teachers to have political access to district and provincial governments. They convey to the higher minister that it is delivered to the district and/or provincial government.

In the midst of health problems, local people use local wisdom, ranging from herbal (traditional) medicine to sharing protein. The head of the tribe has a moral responsibility to maintain the health of its citizens. Together with village heads and religious teachers / pastors, they also mediate between health providers and the community. These health problems cannot be separated from environmental conditions which are obstacles to transportation for optimizing facilities and health personnel.

\section{Acknowledgement}

This research cannot occur without the opportunity given to the author to be involved in health ethnographic research and intervention research. This research is a program from the Center for Humanity and Health Management, Institute for Health Research and Development from the Ministry of Health of the Republic of Indonesia. Because of that, thank you very much. The author also thanks the village head, tribal chief and religious teacher / pastor and family who are willing to be interviewed and observed in their daily lives. A warm and extraordinary reception has an impression on the team. However, this is also inseparable from the support of midwives and nurses, as well as the head of the Primary Health Center (Puskesmas). Through them, we can be well received by the community.

\section{References}

[1] G. Ranis and F. Stewart, "Dynamic Links between the Economy and Human Development," vol. 050, no. 8, pp. 1-16, 2005.

[2] D. P. Bloe, "Development and Human Capital," vol. 1, no. I, pp. 1-14.

[3] L. Jack Jr., M. Grim, T. Gross, S. Lynch, and C. Mclin, "Theory in Health Promotion Programs," in Health Promotion Programms. From Theory to Practice, 1st ed., C. I. Fertman and D. D. Allensworth, Eds. San Fransisco, CA: Jossey-Bass, 2010, pp. $57-$ 88.

[4] T. P. Balitbangkes, IPKM. Indeks Pembangunan Kesehatan Masyarakat, 1st ed. Jakarta: Badan Penelitian dan Pengembangan Kesehatan, 2014.

[5] A. Deaton, "Health, Inequality, and Economic Development," J. Econ. Lit., vol. XLI, no. March, pp. 113-158, 2003.

[6] M. Claeson et al., "Health, Nutrition, and Population," in A Sourcebook for Poverty Reduction Strategies, 1st ed., J. Klugman, Ed. Washingto, DC: World Bank, 2002, pp. 201-230, 543-548. 
[7] The World Bank, "Peningkatan Keadaan Kesehatan Indonesia," pp. 1-4, 2003.

[8] F. S. Sadewo, M. Legowo, and F. Pribadi, "Problematika Akses Kesehatan pada Wilayah Terpencil (Studi Kasus Kabupaten Kepulauan Mentawai, Kabupaten Tojo Una-una dan Kabupaten Teluk Wondama)," in Mengawal Pelaksanaan SDGs (Sustainable Development Goals), 2016, pp. 455-472.

[9] F. S. Sadewo, M. Rahma, E. R. Silambi, and T. J. Angkasawati, Oroma. Merindukan Hidup Sehat Etnik Mairasi, Kabupaten Teluk Wondama, 1st ed. Jakarta: Lembaga Penerbitan Balitbangkes, 2014.

[10] K. S. S. BPS, Statistik Kesejahteraan Rakyat Kabupaten Sorong Selatan 2018, 1st ed. Sorong Selatan: BPS Kabupaten Sorong Selatan, 2018.

[11] K. T. W. BPS, Statistik Kesejahteraan Rakyat Kabupaten Teluk Wondama 2018, 1st ed. Teluk Wondama: BPS Kabupaten Teluk Wondama, 2018.

[12] P. P. B. BPS, Statistik Kesejahteraan Rakyat Provinsi Papua Barat 2017, 1st ed. Manokwari: BPS Provinsi Papua Bart, 2018.

[13] O. Parorrongan, A. Tiniap, and I. B. Windusara, Profil Kesehatan Provinsi Papua Barat 2017, 1st ed. Manokwari: Dinas Kesehatan Provinsi Papua Barat.

[14] K. K. R. Balitbangkes, "Hasil Utama Riskesdas 2018." Badan Penelitian dan Pengembangan Kesehatan Kementerian Kesehatan RI, Jakarta, p. 200, 2018. 